\title{
Land Commitments in Alaska
}

\author{
MAX C. BREWER ${ }^{1}$
}

\begin{abstract}
The Federal government of the United States has, over a number of years, entered into provisional commitments with various owners and agencies in respect to areas of land in Alaska which, in aggregate, exceed the land area of the State by $22 \%$. It is now under pressure from sundry agencies and interest groups to bring additional areas into existing systems of conservation without due study of the problems involved. There will be a consequent lessening in the chances of the State and its Native peoples achieving economic self-sufficiency within a programme of planned land use and protection of the environment. There is need for a single manager of Federal lands, unaffiliated with any existing agencies.
\end{abstract}

RÉSUMÉ. Engagements concernant les terres d'Alaska. Le gouvernement fédéral des Etats-Unis, au cours de plusieurs années, a pris des engagements provisoires avec différents propriétaires terriens et agences en ce qui concerne certaines étendues de terrains en Alaska. Ces terrains, globalement, dépassent de $22 \%$ la surface des terres de l'Etat. Divers groupes de pressions et agences poussent maintenant le gouvernement fédéral à inclure des surfaces additionnelles dans les systèmes de conservation en vigueur, sans pour autant étudier les problèmes en cause. Conséquemment il y aura une diminution des chances de l'Etat et des indigènes à parvenir à une indépendance économique au sein d'un programme planifié d'utilisation des terres et de protection de l'environnement. Une gérance des terres fédérales unique et indépendante des agences déjà existantes s'impose.

РЕЗЮМЕ. Земелъные облзательства на Аляске. В предыдущие годы федеральное правительство СШІА ваяло на себя по договоренности с отдельными собственниками и агенствами ряд временных обязательств, касающихся вемель, которые в обпей сложности на $22 \%$ превытают размеры территорин, принадлежащих правительству штата Аляска. В настолщее время различные агенства и заинтересованные группы настаивают на том, чтобы федеральное правительство включило в существующую спстему охраны вемель дополнительные территории, не занимяясь паучением свяваниых с әтим проблем. Это моэжет привести, однако, к сограпению возможностен птата и его коренного населения, добивающегося әкономпческо независимости в рамках программы планированного испольэования аемель и охраны природы. Необходимо создать такое единое управлекие федеральными землями, которое не было бы свявано ни с одним ия существующих агенств.

The land area of the State of Alaska has been calculated to be 362,516,000 acres $\left(1,468,000 \mathrm{~km}^{2}\right)$ and its inland waters approximately $12,787,000$ acres $(52,000$ $\left.\mathrm{km}^{2}\right)$. Thus, with a grand total of $375,303,000$ acres $\left(1,520,000 \mathrm{~km}^{2}\right)$, there are more than 1000 acres per person for the present population of the State.

At a time when Alaska is being subjected to a redistribution of land ownerships which will have far-reaching consequences, the greater proportion of its land area is still under the control of the Federal ${ }^{2}$ government and its various agencies. Owner-

\footnotetext{
${ }^{1}$ Former Commissioner, Alaska Department of Environmental Conservation (1971-74); former Member, Joint Federal-State Land Use Planning Commission for Alaska (1972-74).

2The term "Federal", as used in this paper, refers to the United States Government at the national level. It encompasses the various departments of the Executive Branch, the Congress and the Judiciary.
} 
ship of the inland navigable waters and the lands beneath them, on the other hand, passed to the State of Alaska with the coming into effect of the Alaska Statehood Act (U.S. Public Law 85-508) on 3 January 1959; and in a report to the National Shoreline Study of the U.S. Army Corps of Engineers, as published in U.S. News and World Report (9 September 1974), it was mentioned that, by virtue of section 6 (m) of the Statehood Act, the submerged lands off the 47,300-mile $(76,000 \mathrm{~km})$ coastline of Alaska to its territorial limit of three nautical miles $(5-6$ $\mathrm{km}$ ) are also reserved to the State.

\section{ALLOCATION OF LANDS}

With such a vast amount of land area available, there has been an understandable tendency for people and agencies to think in terms of large numbers when proposing the allocation of certain areas of the State for specific purposes. It is also understandable that Congress has over the years looked favourably on many of these proposals and has passed enabling acts under which very extensive areas may be committed for purposes deemed desirable. Additionally, the Department of Interior has issued various public land orders designating large blocks of land for specific uses.

Unfortunately, with this piecemeal approach to the disposal of lands in Alaska by various groups over periods of time, there has often been a lack of careful attention given to whether the areas of the requested lands have been determined realistically in the light of their declared purposes. Even less attention has been given as to how the allocations might be equated to the total areas available. This last problem has been compounded by the slowness in the transfers of actual title to the lands committed. As a result, in 1975 approximately $442,856,000$ acres $\left(1,793,000 \mathrm{~km}^{2}\right)$ of land in Alaska have been provisionally committed, set aside in the form of land withdrawals, or designated for specific uses (see Table 1), although the total available area is only $362,516,000$ acres $\left(1,468,000 \mathrm{~km}^{2}\right)$. While it is true that some of these withdrawals or designations may be only temporary, an analysis of them is required because of problems entailed, both existing and potential.

In addition to the areas listed in Table 1,168 areas ranging in size up to approximately 25,600 acres $\left(100 \mathrm{~km}^{2}\right)$ have been nominated for designation as ecological or geological reserves. Some of these are located within areas provisionally designated for other purposes.

From the data shown in Table 1, it would appear that the land area of Alaska has been overcommitted to the extent of some 80 million acres $\left(324,000 \mathrm{~km}^{2}\right)$; and so, if the U.S. Bureau of Land Management were called upon to issue title to each of the proposed land owners in 1975 , it could not do so without running out of land.

In numerous instances, lands in Alaska have been committed to more than one potential owner, and thus there is an overlap or a duplication in some of the figures shown in Table 1. For example, 400,000 acres $\left(1 ; 620 \mathrm{~km}^{2}\right)$ of existing national forest lands were promised to the State of Alaska under the Statehood 
Act; and another 23,040 acres $\left(93 \mathrm{~km}^{2}\right)$ of national forest or national wildlife refuge lands (Kodiak) were promised to each of the Native communities located within or adjacent to the cities of Ketchikan, Sitka, Juneau, and Kodiak, in accordance with the terms of the Alaska Native Claims Settlement Act (U.S. Public Law 92-203). Other Native communities were to receive part of their allotment from within existing national wildlife ranges and refuges, which would be replaced by other lands - from within Naval Petroleum Reserve No. 4, from within the Rampart Canyon power site withdrawal, or from State lands already selected or tentatively approved, but not yet patented. These overlapping land commitments or designations amount to some $13,162,000$ acres $\left(53,000 \mathrm{~km}^{2}\right)$ including $1,196,000$ acres $\left(4,900 \mathrm{~km}^{2}\right)$ of State patented land, as of December 1972.

Under section 11 (a)(3)(A) of the Settlement Act, the U.S. Secretary of Interior was required to withdraw three times the land entitlement for a village or regional corporation, whenever there were insufficient lands available for selection from areas surrounding the villages. These areas - referred to as deficiency lands plus those townships designated under section 11(a)(1) and section 11(a)(2) of the Act make up the 102,101,000 acres $\left(414,000 \mathrm{~km}^{2}\right)$ indicated as "Lands withdrawn for Native selection" in Table 1. Theoretically, a net area of $62,101,000$ acres $\left(252,000 \mathrm{~km}^{2}\right)$ of these lands returns to the public domain on 18 December 1975, after the land selections by native village and regional corporations have been completed. However, Public Land Order 5418 (Alaska), withdrawing lands for classification and for protection of the public interest, includes the statement that "all unreserved public lands in Alaska, or those which may become unreserved unless specified by order at that time." Thus, there is some question as to when, if ever, these lands are likely to become available to meet some of the land commitments already made.

After 18 December 1975, the use of these lands, plus some of the designated public interest lands, could serve to fulfil existing land commitments. However, even before the existing confusion has been resolved, further attempts are being made, following the passage of the Settlement Act, to commit more acreage in Alaska for conservation purposes.

The first attempt was a proposal to the Republican Platform Committee, in August 1972, to withdraw another 125 million acres $\left(506,000 \mathrm{~km}^{2}\right)$ for conservation purposes (Eastaugh 1973). This proposal was abandoned when the Committee was informed that, after the passage of the Settlement Act, insufficient land was left for a withdrawal of that magnitude. In January 1973, House of Representatives Bill 2295 was introduced in Congress with 11 sponsors. It called for the creation, or extension, in Alaska of nine national wildlife refuges and one national wildlife range, with an aggregate area of $67,904,000$ acres $\left(275,000 \mathrm{~km}^{2}\right)$. A large number of villages and towns, including Fairbanks - the second largest city in the State - and the entire Prudhoe Bay oil field, would have been included within the proposed wildlife refuges; and four of them would have been intersected by the route of the trans-Alaska oil pipeline. Essentially all of the existing and potential petroleum areas of Alaska, including most of Naval Petroleum 
TABLE 1. Commitments, existing and proposed of lands in Alaska by the U.S. Federal government (in $10^{3}$ acres $=4 \mathrm{~km}^{2}$ approx.)

Department of Agriculture (National forests)

Chugach National Forest

20,742

Tongass National Forest

4,726

16,016

Department of Defense

Air Force (Alaskan Air Command and American Defense Command)

Army

1,754

Navy (excluding Naval Petroleum Reserve No. 4)

Naval Petroleum Reserve No. 4

(including Naval Arctic Research Laboratory)

23,680

Department of Interior (Fish and wildlife ranges and refuges) 1

Arctic National Wildlife Range

19,918

Clarence Rhode National Wildlife Range

8,900

Aleutian Islands National Wildlife Refuge

2,887

Kodiak National Wildlife Refuge

2,720

Kenai National Moose Range

1,815

Nunivak National Wildlife Refuge

1,730

1,109

Izembek National Wildlife Range

Cape Newenham National Wildlife Range 265

Ten other small national wildlife refuges

Department of Interior (National parks and monuments)

Glacier Bay National Monuments

$2,273^{2}$

Katmai National Monument

2,792

Mount McKinley National Park

1,940

Department of Interior (Native reserves and schools)

Department of Interior (Pipeline corridors)

6,942

Department of Interior (Power site withdrawals)

Rampart Canyon site

Several smaller sites

Department of Interior (Proposed new amenities) 5

National forests

National monuments and parks

National wildlife ranges and refuges

National wild and scenic river system

Replacement lands for wildlife refuges ${ }^{6}$

Department of Interior (Public interest lands)

Withdrawn for classification and protection:

(a) under Public Land Order no. 5180"

40,4049

(b) under Public Land Order no. 541810 
TABLE 1 (continuation).

TOTAL: Departments of Agriculture, Defense, Interior and Transportation

(103 acres $\left.^{*}\right)$ 234,440

Lands withdrawn for Native selection of $40,000,000$ acres by village and regional corporations 11 (as of December 1972)

102,101

Private patented lands (as of December 1972)

State land entitlement 12 105,350

From within the national forests

From within other public lands, including national forests, for community development

General grant of lands with statehood

Mental health land grant

University of Alaska, Land Grant College

1. See Weeden 1973.

2. $2,803 \times 10^{3}$ acres with some water coverage included.

3. Includes seven villages, which have opted to retain their existing reserves, which are as follows:

\begin{tabular}{lr} 
Arctic Village and Venetie (1943) & 1,408 \\
Elim (1917) & 316 \\
Gambell and Savoonga, St. Lawrence Island (1903) & 1,205 \\
Klukwan (1912-22) & 892 \\
Tetlin (1930) & $\mathbf{7 6 8}$ \\
& $\underline{3,697}$ \\
\hline
\end{tabular}

4. Includes the sites of several existing villages. See F.F.C.D.P.A. 1968.

5. Under section 17(d)(2)(A) of the Alaska Native Claims Settlement Act.

6. Under section 22(e) of the Settlement Act.

7. These areas are constantly being re-evaluated and changed slightly, due to redefinition of boundaries.

8. Issued 9 March 1972 under section 17(d)(1) of the Settlement Act. The lands are not open to Native or State selection or entry under the public land laws.

9. As of December $1972,45,474 \times 10^{3}$ acres were included in this category; the reduction to $40,404 \times 10^{3}$ acres since that date is accounted for by an increase of 5,070 x $10^{3}$ acres in "Proposed new amenities" lands (note 5 above).

10. Issued 29 March 1974 (as amendment of Public Land Order No. 5180) under section 17(d)(1) of the Settlement Act. The lands are not of sufficient interest to be requested by Native regional corporations or the State.

11. Under section 11 of the Settlement Act.

12. Selection rights granted under the Alaska Statehood Act. 
TABLE 2. Areas proposed for national conservation systems

\begin{tabular}{lccc}
\hline $\begin{array}{l}\text { National system } \\
\text { or administration }\end{array}$ & $\begin{array}{c}\text { Existing area } \\
\text { in 103 } \text { acres* }\end{array}$ & $\begin{array}{c}\text { Area added in 103 } \text { acres* }^{*} \\
\text { By Bill S. 2917 }\end{array}$ & By Bill S. 2918 \\
\hline National forests & 20,742 & 18,800 & 1,600 \\
$\begin{array}{l}\text { National monuments and parks } \\
\text { National wildlife }\end{array}$ & 7,005 & 32,260 & 59,700 \\
$\quad$ ranges and refuges & 19,919 & 31,590 & 43,200 \\
$\begin{array}{l}\text { National wild and } \\
\quad \text { scenic river system }\end{array}$ & & 820 & 1,594 \\
Totals & 47,666 & 83,470 & 106,094 \\
\hline
\end{tabular}

${ }^{*} 10^{3}$ acres $=4 \mathrm{~km}^{2}$ approximately

Reserve No. 4, would have been designated as wildlife refuges or ranges, had the bill become law.

Senate Bill 2917, introduced in Congress in January 1974 at the request of the Secretary of Interior as required under the terms of the Settlement Act (section $17(d)(2)(A)$, provided for the designation of $83,470,000$ acres of land $(338,000$ $\mathrm{km}^{2}$ ) for new or expanded national forests, monuments, parks, wildlife ranges, wildlife refuges and the wild and scenic river system (see Table 1). It has, however, been contended in some quarters that the Secretary, in making his proposals, exceeded the intent of the Act, which requires designated areas to be "up to, but not to exceed, eighty million acres of unreserved public lands". It has further been contended that far more attention was paid to conservation pressure groups fighting for particular areas of land than to the good conservation principles contained in the recommendations.

Senate Bill 2918, also introduced in Congress in January 1974, at the request of several conservation groups, provided for an increase in the total area to be allotted to these conservation systems, but required it to be divided up in a far different manner (see Table 2), without any significant enlargement of the existing national forest system in Alaska. The Bill would also provide, wherever possible, for the inclusion of territorial waters belonging to the State.

Both Senate Bills - particularly S 2918 - make effective provision for the acquisition of additional areas for conservation from within the State's territorial waters by means of agreements with various groups and - in the case of S 2918 - from withdrawn or deficiency lands not selected by Native groups.

\section{EFFECTS OF THE OVERCOMMITMENT OF LANDS}

\section{General}

One of the declared prime purposes of the Statehood Act was to provide a grant of lands in order to make it possible for Alaska to become an economically viable entity. A similar purpose was intended for the Natives with the passage of the Settlement Act (sections 7(d) and 11), particularly since, under its terms, they accepted a measure of Federal government restriction on their subsistence hunting and motorized travel over what had formerly been lands in the public domain. 
The path towards economic viability, however, lay in the wise development of natural resources, both renewable and non-renewable. Unfortunately, section 17(d)(2) and, to a lesser degree, section 17(d)(1) of the Settlement Act tend to negate the avowed intention of Congress to promote the economic viability of Alaska and its Native peoples. Indeed, the Act might more appropriately have the title "Alaska Conservation Act of 1971."

Many of the Native leaders were quick to seize upon the fact that it was the land, not the money provided, that would really count in any claims settlement. Under the Settlement Act, they received 40 million acres $\left(162,000 \mathrm{~km}^{2}\right)$ of land, but were not provided with a means of getting to market any of the resources it might contain. Under the same Act, the four conservation systems received 80 million acres $\left(324,000 \mathrm{~km}^{2}\right)$ - perhaps indeed considerably more - in addition to the $47,665,000$ acres $\left(193,000 \mathrm{~km}^{2}\right)$ already assigned to them; and after the village corporations had made their selections of land (including and immediately surrounding the villages) the same conservation systems would, in making selections, have priority over both the Native regional corporations (the profit-making bodies working in the Native interest) and the State. In the latter instance, because of the land freeze existing since 1966 , almost 80 million acres $\left(324,000 \mathrm{~km}^{2}\right)$ of land entitlement under the Statehood Act still remained to be selected. Under the conditions of the Settlement Act, and after a review of the information contained in Table 1, it becomes rather obvious that the word "select" appearing in section 6 (b) of the Statehood Act might be regarded as largely academic.

According to section 11(a)(3)(A) of the Settlement Act, "the Secretary shall, insofar as possible, withdraw public lands of a character similar to those on which the village is located and in order of their proximity to the center of the Native village". Strong and serious complaints have been voiced, and lawsuits initiated, by Native groups in this regard, particularly by those living along the coast. They claim that, because the conservation systems had priority, these "similar lands" too often were mountain tops and glaciers, which historically they did not use, or were lands which they had never seen or used, located across the waters. The latter problem is well illustrated in the case of the Nunivak Island residents, whose deficiency lands have been described by some of the islanders as mosquito-infested swamps located on the mainland. To get to these lands, which most of the Nunivak people have never seen, requires crossing 23 miles $(37 \mathrm{~km})$ of often-stormy sea, and then crossing a roadless wildlife range on the mainland. These people, whose ancestors have occupied Nunivak Island continuously for at least 2,000 years (U.S.D.I. 1973), cannot take their full land entitlement on the Island, because it was designated as a $1,109,000$ acre $\left(4,500 \mathrm{~km}^{2}\right)$ national wildlife refuge under Executive Order 5095 of 15 April 1929. The refuge was established largely for the protection of two species: reindeer, introduced in 1920, and muskox, introduced in 1935. The Natives and cliff-nesting sea birds have coexisted over the centuries, apparently without upsetting the natural equilibrium. Under Federal management, the reindeer, lacking natural enemies and overgrazing their range, have suffered one severe depletion of population - from about 25,000 to some 700 animals - but the number has since increased again to over 4,000 animals. 
The muskox population, also under Federal management, has been in severe trouble, as a result of overgrazing their range, for several years.

Another problem facing many Native communities is that, under the existing conservation withdrawals but to a far greater degree under the proposed withdrawals, their communities are often completely surrounded by wildlife refuges. Many Natives are very uneasy about this prospect because of past experiences at the hands of local managers of ranges and refuges - particularly those with little acquaintance or sympathy with the subsistence way of life. The stated objectives of Senate Bills 2917 and 2918 - that the wildlife refuges be studied with a view to their preservation as wilderness areas with all the attendant implications and restrictions - provide little feeling of security for people following a subsistence way of life, or for those Natives who might wish to develop their lands with the aid of some form of surface transportation.

\section{Land use planning}

Very few maps of Alaska provide a full indication of lands already withdrawn, or proposed for withdrawal, for various specific purposes, and of existing patterns of ownership. A valid reason for the absence of such maps is that they would be far too full of detail to be readily intelligible. Furthermore, they would, if produced, make it all too obvious just how badly the State has been artificially and excessively divided up in a vain effort to serve too many very specific interests and to comply with too many basically conflicting requirements in law.

Most of the commitments for land ownership in Alaska were made without the benefit of any land-use planning. They were often made on the basis of the personal desires or observations of a few individuals intensely interested in promoting some single development, or in protecting some aspect of the environment. Rarely was even a superficial inventory made of an area before its designation. Often there was a blurring of such knowledge as was available, for fear that it might stand in the way of action being taken on a proposal of considerable immediate interest. There has also been wide acceptance of the philosophy that "big" is synonymous with "good" and that, if protection of an area is desired, it should be achieved through the creation of a buffer zone which should itself have a zone of protection. Thus, there is a tendency to commit huge blocks of land, five to ten million acres $\left(20,000-40,000 \mathrm{~km}^{2}\right)$ at a time, for specific purposes. It was in these circumstances that the Joint Federal-State Land Use Planning Commission for Alaska was created in July 1972, as required under section 17(a)(1) of the Settlement Act.

The Commission, which is advisory only, was not created until after the designations and identifications had already been announced for the Native deficiency lands, for most of the lands to be considered for the four conservation systems, and for the lands to be considered for the public interest. The Commission has the right, within limits, to make recommendations for the modification of some of the proposed uses of lands. However, to date it has not played a significant role in designating the uses, the natural boundaries, or the appropriate size for the various lands withdrawn and classified as a result of the Settlement Act. This situation arises in part from the excessive dividing up already legislated for by 
Congress; in part because of the Commission's lack of standing in relation to the Secretary of Interior. The latter problem was exemplified by a statement, generally attributed to an Assistant Secretary of Interior, and made public in the Anchorage Daily News of 5 December 1973, in which a defence was made of the Secretary's decision to essentially reverse the Commission's recommendations regarding the extent of the lands proposed for single-use, as opposed to multipleuse, classification. He is quoted as saying: "There were some variations in philosophical approach between the Commission's majority and the Secretary of Interior. This has led to some recommendations by the Secretary which I suspect the Commission would not endorse." The problem was further exemplified by the creation within the Department of Interior of the Alaska Task Force, with an Assistant Secretary as chairman, to perform as an internal operation the same thing that the Commission, with its resource team, was created to accomplish. Additionally, the Department of Interior's conservation agencies, working on the classification of the lands in Alaska, were not allowed to present their individual proposals for the classifications to the Commission, in spite of the requirements of section 17(a)(6)(B) of the Settlement Act.

It is thus apparent that the Commission was not considered by the Secretary of Interior to be sufficiently preservationist-oriented. This evaluation may be compared with that of a former representative of the Alaska Conservation Society who has written: "The make-up of the Commission as a whole suggests that a protective rather than managerial or cropping view of wildlife issues will dominate that segment of the group's interests", (Weeden 1973 p. 36).

To be effective, land use planning requires an inventory of the resources available and a knowledge of the requirements, interactions, and compatibilities among the various potential users of the resources. Only when that planning has been done can the question of precise boundaries be grappled with. Managerial systems, sufficiently flexible to adjust to the particular environments involved, are also necessary. These principles have not been observed by the Federal government in its approach to land-use planning in Alaska. Lands have been tentatively committed to various authorities before their potential uses have been properly determined and the most appropriate patterns of management property considered. In such circumstances, effective state-wide planning of land-use in Alaska is impossible.

\section{Conservation}

Conservation, as meaning the wise use of lands and resources, although so often rendered lip service, seems not to have been a priority consideration in what amounts to a power struggle concerning the lands of Alaska (though an exception to this statement is provided in the case of some of the Native corporations). Rather, what is being witnessed is a classic battle - before Congress, among government agencies, and among the public - between developers and preservationists. These groups are better known for their more extreme approaches to the problem than for their successes as land managers.

Senate Bill 2917 would require the Secretary of Interior, within three years (except in the case of the Noatak National Arctic Range), to report his recom- 
mendations concerning the suitability or non-suitability of the various units for preservation as wilderness. The recommendations would cover all of the units added to the already-established conservation areas, or newly-established areas, as parks, monuments, national reserves, wildlife refuges or wildlife ranges. Senate Bill 2918 would require the Secretaries of Interior and Agriculture within ten years to study all lands and waters within the boundaries of their respective areas of jurisdiction, and described in the Bill, with regard to their suitability for inclusion as units of the National Wilderness Preservation System.

It would seem, therefore, that both Bills - but more particularly S 2918 are very heavily biased in favour of preservation rather than conservation, good wildlife management and enjoyment by ordinary people. This view is lent support as a result of proposals made by agencies to designate as wilderness the entire areas of the Arctic National Wildlife Range, Glacier Bay National Monument, and much of the area of the Kenai Moose Range. Certainly preservation of wilderness in generous amounts in well considered areas is desirable, even though as Weeden (1973) and others have pointed out, there is an important distinction between preservation of wilderness and preservation of fish-and-wildlife habitat. While in some instances the two may be compatible, the former does not provide for improvement of habitat or management of wildlife. In Alaska, where sparseness of population has to be considered in conjunction with the realities of budgeting at both the Federal and State levels, there is also the possibility that enforced protection of wildlife would be lessened in areas designated as wilderness, if these were too large or too numerous.

Weeden (1973) has indicated on maps some twenty of the well-defined major areas of waterfowl production, migration and hunting in Alaska, though not the tremendous tracts of land which are the subject of Senate Bills 2917 and 2918. Similar maps could be developed for other birdlife, for various game animals, for fish, for scenic beauty, for recreational opportunities and for potential wilderness experiences. The areas concerned could be given buffer protection without the need for protracted haggling over precise dimensions. Standing out of the ordinary, they would attract the support of many people, including those in a good position to ensure continuing protection.

Weeden also (1973) quotes a former divisional director of the Alaska Department of Fish and Game as saying, in 1966, at a meeting convened to establish a lands programme: "We don't want to administer lands, we want to influence administration." The approach could be recommended to a number of agencies - to influence the management of lands and to develop appropriate classifications, instead of competing over who becomes the manager of the greatest area. It might also serve to offset a certain lack of candour which exists at present in the classification of lands. For example, credibility is impaired when an area containing hardly any trees is designated as a national forest simply in order to obtain a management that can allow mining. In a similar vein, it strains the imagination when an area with very little wildlife is designated a national wildlife refuge simply because there is a desire for its wilderness character to be maintained.

In a like category are the various projecting slivers of land, six miles $(9.5 \mathrm{~km})$ and twelve miles $(19 \mathrm{~km}$ ) wide, that were included in various conservation systems 
in order that pieces of land left vacant by the mapmakers might be taken in. Such slivers inhibit effective planning of land use.

Whereas it is assumed that adjustments can eventually be made to enable the Federal Government to fulfil the commitments it has made to date, existing policies for the allocation of available land could lead to the virtual elimination of public domain lands in Alaska. Instead of having, as to date, basically one Federal land manager for about 80 per cent of the land in the state, there would be many government land managers, each subject to different regulations, and each working within irrational land boundaries, and each operating more or less independently.

It is unrealistic to assume that there will be no future development in Alaska. The recent corridor proposals circulated by the Bureau of Land Management (U.S.D.I. 1974), and the requirement, in section 17(b)(3) of the Settlement Act, that the Secretary of Interior reserve public easements, provided an indication that some development, particularly as regards energy, is probable. The expressed intent of Congress to provide for the economic viability of the State and its Native peoples makes some development essential. However, the inevitable barriers resulting from the proposed excessive subdivision of lands owned by Federal agencies, with their relatively inflexible managerial structures, could well result in any future development proceeding in a manner far more damaging to the environment than would be necessary. The creation of irrational land barriers, examples of which already exist in Alaska, and the problems inherent in them could be expected to greatly increase the public cost of the future development and cause unnecessary hardship to numerous individuals.

Protection of the environment requires careful land-use planning, effective and straightforward implementation of realistic controls on development, and a commitment to efficient management. This protection and conservation cannot be accomplished if development is forced to occur in unnatural ways: for example, by the construction of roads through permafrost swamps or down too-steep slopes, causing erosional sores that will remain on the landscape for tens of years; by the laying of pipelines the long way around square-cornered withdrawals or through difficult obstacle courses; or by communities being established in areas where hillsides have to be cut down, waterways continually dredged and great quantities of gravel excavated to fill in swamps. Neither protection of the environment nor conservation are likely to be aided by the replacement of engineering judgments with biological opinions. Admittedly, engineers have not been forced to consider environmental values in the past. However, there is little evidence that biologists will be inclined to consider engineering limitations in the future. The existing proposals for land ownerships in Alaska, although intended to correct past abuses and to prevent future abuses of lands, will instead lead to a greater incidence of land abuses. The best that can be said for these prospective abuses is that they would tend to be concentrated into corridors and swaths of land. The overcommitment of lands in Alaska, with land areas the subject of departmental rivalries, can only intensify these problems.

Consideration needs to be given to the establishment of a single management agency for all Federal lands in Alaska, having no affiliations with the existing Federal units of land management. It should be charged with the promotion of 
land policies that are appropriate to sub-arctic and arctic environments, instead of remaining tied to the often outmoded philosophies, policies and regulations developed in earlier years for application to temperate environments. It should devote particular attention to the identification of those naturally-defined areas having specific conservation values, and manage them according to the technical criteria established by groups and agencies having the requisite expertise in the field of conservation. Such an approach in Alaska would constitute a break with past practices, which have not really worked elsewhere, rather than perpetuate them. It would also serve to foster cooperation, rather than competition, among the Federal agencies, the State and the private land owners.

\section{REFERENCES}

EAstaugh, F. o. 1973. Testimony presented before the Joint Federal-State Land Use Planning Commission, Juneau, Alaska, May 17, 1973.

F.F.C.D.P.A. 1968. (Federal Field Committee for Development Planning in Alaska), Alaska Natives and the Land. Washington, D.C.: Government Printing Office.

U.S.D.I. 1973. Nunivak Wilderness Study Summary. Washington, D.C.: U.S. Department of Interior, Fish and Wildlife Service.

U.S.D.1. 1974. Multimodal Transportation and Utility Corridor Systems in Alaska. Washington, D.C.: U.S. Department of Interior, Bureau of Land Management.

WEEDEN, R. B. 1973. Wildlife Management and Alaska Land Use Decisions. Fairbanks: University of Alaska (I.S.E.G.R. Occasional Paper no. 8). 